\title{
PUTUSAN ULTRA PETITA MAHKAMAH KONSTITUSI DALAM PENGUJIAN UNDANG-UNDANG (SUATU PERSPEKTIF HUKUM PROGRESIF)
}

\author{
Hery Abduh Sasmito, SH
}

\begin{abstract}
Doktrin larangan ultra petita bagi hakim tidaklah berlaku mutlak dan umum. Dengan menggunakan pendekatan normatif dan penafsiran sistemik dapat dikatakan bahwa ketentuan dalam Undang-Undang MK maupun Peraturan MK tidak memberikan kemungkinan bagi hakim konstitusi untuk membuat putusan ultra petita. Dalam menerbitkan putusan yang mengandung ultra petita, pada umumnya MK mendasarkan adanya keterkaitan yang tidak terpisahkan antara pasal yang diuji dengan pasal-pasal lain yang tidak diuji, sehingga karenanya pasal atau seluruh undang-undang tersebut harus dinyatakan tidak berkekuatan hukum, di samping karena alasan untuk menghindari kekacauan hukum dan menegakkan keadilan subtantif. Terobosan MK dalam membuat putusan ultra petita pada prinsipnya adalah bentuk dari penegakan hukum yang progresif, akan tetapi kreatifitas apapun yang dilakukan oleh penegak hukum dapat menjadi tidak bermakna progresif manakala tidak untuk mewujudkan keadilan subtantif, menempatkan keadilan, kemanfaatan dan kebahagiaan manusia sebagai tujuan akhirnya.
\end{abstract}

Kata kunci : Ulta Petita, Pengujian Undang-Undang, Hukum Progresif.

\section{A. PENDAHULUAN}

\section{A.1. Latar Belakang}

Keberadaan peradilan konstitusi memiliki kedudukan yang penting dalam sistem ketatanegaraan Indonesia. Pembentukannya sejak awal dimaksudkan untuk menyelesaikan perkara-perkara yang erat kaitannya dengan konstitusionalitas penyelenggaraan negara dan masalah-masalah ketatanegaraan di Indonesia. Dalam Pasal 2 UU No.24 Tahun 2003 tentang Mahkamah Konstitusi disebutkan, bahwa "Mahkamah Konstitusi merupakan salah satu lembaga negara yang melakukan kekuasaan kehakiman yang merdeka untuk menyelenggarakan peradilan guna menegakkan hukum dan keadilan. Dalam menjalankan fungsi peradilan tersebut
Mahkamah Konstitusi memiliki kedudukan yang sederajat dengan lembagalembaga negara lainnya, termasuk koleganya Mahkamah Agung.

Berdasarkan Pasal 24C UUD NRI Tahun 1945 juncto Pasal 10 UndangUndang Nomor 24 Tahun 2003 tentang Mahkamah Konstitusi (UU MK), Mahkamah Konstitusi sebagai lembaga negara pemegang kekuasaan kehakiman diberikan 4 (empat) kewenangan dan 1 (satu) kewajiban, yaitu ${ }^{22}$ :

\footnotetext{
22 Pasal 24C jo Pasal 10 UU Nomor 24 Tahun 2003 tentang Mahkamah Konstitusi
} 
1. Menguji undang-undang terhadap Undang-Undang Dasar Negara Republik Indonesia Tahun 1945;

2. Memutus sengketa kewenangan lembaga negara yang kewe-nangannya diberikan oleh UUD NRI Tahun 1945;

3. Memutus pembubaran partai politik; dan

4. Memutus perselisihan tentang hasil pemilihan umum; serta

5. Kewajiban memberikan putusan atas pendapat DPR bahwa Presiden dan/atau Wakil Presiden diduga telah melakukan pelanggaran hukum berupa pengkhianatan terhadap negara, korupsi, penyuapan, tindak pidana berat lainnya, atau perbuatan tercela, danlatau tidak lagi memenuhi syarat sebagai Presiden dan/atau Wakil Presiden sebagaimana dimaksud dalam Undang-Undang Dasar Negara Republik Indonesia Tahun 1945.

Kehadiran MK telah banyak memberi sumbangan bagi penye-hatan sistem ketatanegaraan dan hukum kita. ${ }^{23}$ Mahkamah Konstitusi yang hanya memiliki 9 (sembilan) Hakim Konstitusi dipandang memiliki produktivitas yang tinggi. Dalam usia yang relatif masih sangat muda tersebut, Mahkamah Konstitusi telah banyak menghasilkan putusan-putusan yang telah mewarnai

${ }^{23}$ Mahfud MD, Perlukah Amandemen ke lima UUD 1945, Makalah pada Konvensi Hukum Nasional UUD 1945, sebagai landasan konstitusional Grand Design Sistem dan Politik Hukum Nasional yang diselenggarakan oleh BPHN Departemen Hukum dan HAM, Jakarta 15-16 april 2008. pemikiran dan kehidupan ketatanegaraan Indonesia. Diskursus dan pemikiran mengenai hukum ketatanegaraan menjadi dinamis dan lebih menarik perhatian khalayak luas.

Meskipun begitu, banyak pula kontroversi yang muncul terkait dengan putusan-putusan Mahkamah Konstitusi dalam pe-ngujian undang-undang. Tidak se-dikit praktisi maupun akademisi hukum yang mengkritik tindakan MK tersebut. Menurut Adnan Buyung, beberapa masalah pelik yang ditimbulkan oleh MK salah satunya terkait dengan pembatalan sifat melawan hukum materiil dalam Undang-Undang Tipikor dan masalah pelanggaran doktrin larangan ultra petita. Dalam kasus pengujian UndangUndang Komisi Yudisial misalnya, MK telah menghapuskan segala kewenangan KY untuk mengawasi dan memeriksa perilaku dan hakim di lingkungan Mahkamah Agung, padahal masalah tersebut tidak pernah diminta para Pemohon (Hakim Agung Prof. Dr. Paulus Efendi Lotulung dkk.) untuk dibatalkan. ${ }^{24}$ Mahfud MD sebelum manjadi Ketua MK juga pernah menyatakan bahwa terdapat beberapa masalah dalam putusan MK. Ada beberapa putusan MK yang bersifat ultra Petita yang mengarah pada intervensi ke dalam bidang legislasi. Ada juga putusan yang dapat dinilai melanggar asas nemo judex in causa sua, serta putusan yang cenderung mengatur atau putusan yang didasarkan pada

\footnotetext{
24 Lihat dalam Adnan Buyung Nasution, "Quo Vadis" Hukum dan Peradilan di Indonesia, Artikel dalam Harian Kompas edisi 22 Desember 2006.
} 
pertentangan antara satu undang-undang dengan undang-undang yang lain. ${ }^{25}$

Tudingan bahwa MK dianggap sebagai lembaga yang superbody pun menggejala. Keten-tuan UUD yang menyatakan bahwa putusan Mahkamah Konstitusi bersifat final dan mengikat seolah-olah menjadi senjata ampuh yang memperkuat anggapan tersebut. Tudingan-tudingan bahwa hakim MK bertindak tidak netral, ada pesanan-pesanan khusus dari pihak tertentu, kepentingan-kepentingan kelompok dan uang menjadi dua hal yang paling sering diasumsikan orang sebagai hal yang dapat mempengaruhi putusan MK. ${ }^{26}$ Wajar saja, karena memang adakalanya lembaga ini membuat putusan-putusan yang justru dapat dinilai melampaui kewenangan konstitusi-onalnya. ${ }^{27}$ Singkatnya, banyak yang mencibir lembaga baru ini, tapi tak sedikit pula yang menunggu kiprahnya untuk menegakkan hukum dan keadilan.

Perdebatan kemudian mengerucut pada opini, apakah memang Mahkamah Konstitusi boleh membuat putusan yang mengandung ultra petita. Apakah amar putusan yang sifatnya ultra petita dalam pengujian undang dibenarkan oleh Undang-Undang Mahkamah Konstitusi. Banyak pakar hukum yang memperbolehkan, tapi tak sedikit juga

25 Mahfud MD, Konstitusi dan Hukum dalam Perdebatan Isu, Rajawali Press, Jakarta. 2009. hal. 278. Permasalahan yang terakhir ini misalnya nampak dalam pengujian norma calon Pilkada Perseorangan dalam UU Pemerintahan Daerah yang dikaitkan dengan UU Pemerintahan Aceh.

26 Harjono, Konstitusi Sebagai Rumah Bangsa, Setjen dan Kepaniteraan MKRI, Jakarta, 2008. hal.166-167.

${ }^{27}$ Mahfud MD, Konstitusi,............ Op.cit. hal. 278. yang menyatakan tidak boleh. Mantan Ketua MK, Jimly Asshiddiqie misalnya mengatakan, "boleh saja putusan MK memuat ultra petita jika masalah pokok yang dimintakan review terkait pasalpasal lain dan menjadi jantung dari UU yang diuji. Sementara Mahfud MD dan mantan Hakim Agung Benjamin Mangkoedilaga, berpendapat bahwa MK tak boleh membuat putusan ultra petita tanpa pencantumannya di dalam UU. ${ }^{28}$

Wacana dan diskursus yang berkembang, ada sebagian pakar hukum yang menginginkan agar putusan ultra petita tersebut dilarang dengan memasukkannya dalam amandemen Undang-Undang Mahkamah Konstitusi. ${ }^{29}$ Sebagian menganggap diperlukannya amandemen UU MK dengan mencan-tumkan diperbolehkannya putusan yang mengandung ultra petita dengan pembatasan-pembatasan yang ketat. Sebagian yang lain berpandangan bahwa tidak diperlukan amandemen dan menganggap praktek MK tersebut sebagai bagian dari judicial activism.

Menarik untuk ditelaah pernyataan Mahfud MD dalam acara focus group discusion yang diselenggarakan oleh

${ }^{28}$ Lihat dalam Mahfud MD, Mendudukkan Soal Ultra Petita, Artikel diunduh dari laman : http://www.kompas.com/kompas-

cetak/0702/05/opini/3289700.htm, akses taggal 20 Agustus 2010.

29 Wacana larangan MK untuk tidak membuat putusan yang bersifat ultra petita yang termaktub dalam RUU perubahan terhadap UU No. 24 Tahun 2003 tentang Mahkamah Konstitusi (MK) semakin hangat. Lihat artikel “Jangan Sampai MK Merasa Sebagai Lembaga Tertinggi Negara : Revisi UU MK, www.hukumonline.com, akses tanggal 22 September 2007. 
Badan Pembinaan Hukum Nasional pada tanggal 2 November 2010, dengan tema "Dinamika MK dalam Mengawal Konstitusi". Menurut Mahfud, dalam melaksanakan kewe-nangannya, MK memiliki rambu-rambu yang harus ditaati. Rambu-rambu tersebut misalnya: putusan MK tidak boleh berisi norma (bersifat mengatur), MK tidak boleh memutus melebihi permohonan (ultra petita), atau dalam hal Perselisihan Hasil Pemilihan Umum hanya berwenang memutus perselisihan atau kesalahan rekapitulasi penghitungan suara. Namun dalam praktiknya rambu-rambu tersebut sulit selalu ditaati. MK, terkadang, perlu membuat terobosan-terobosan hukum (rule breaking) untuk mewujudkan keadilan. $^{30}$

Jika memang demikian, maka ada kecenderungan pemikiran hukum progresif dikalangan hakim konstitusi. Pertanyaannya selanjutnya adalah apakah pemikiran-pemikiran yang progresif tersebut juga nampak dalam putusan-putusan Mahkamah Konstitusi yang mengan-dung ultra petita. Apakah terobosan-terobosan MK dalam membuat putusan yang mengandung ultra petita dapat di-kategorikan sebagai tindakan-tindakan progresif yang berani melawan arus demi mewujudkan keadilan subtantif.

Berangkat dari latar pemikiran di atas, maka penulis merasa tertarik untuk melakukan penelitian dengan judul "Putusan Ultra Petita Mahkamah Konstitusi Dalam Pengujian Undang-

30 Mahfud MD dalam, Menabrak Rambu-Rambu Demi Keadilan Subtantif, Berita diunduh dari: http://www.mahkamahkonstitusi.go.id/index.p hp ?page=website. BeritalnternalLengkap\&id $=47$ 19, akses tanggal 3 Nopember 2010.
Undang (Suatu Perspektif Hukum Progresif)".

\section{A.2. Permasalahan}

Dari latar belakang masalah tersebut di atas, maka terdapat beberapa pokok permasalahan yang akan diteliti dalam penelitian ini yaitu:

a. Bagaimanakah kedudukan putusan ultra petita dalam pengujian undangundang berdasarkan ketentuan normatif?

b. Apakah yang menjadi pertimbangan dibuatnya putusan Mahkamah Konstitusi yang mengandung ultra petita dalam pengujian undang-undang ?

c. Bagaimanakah prespektif hukum progresif terhadap putusan ultra petita Mahkamah Konstitusi dalam pengujian undang-undang?

\section{A.3. Tujuan Penelitian}

Sebagai tindak lanjut dari rumusan masalah yang telah ditetapkan di atas, maka tujuan dalam penelitian ini adalah sebagai berikut:

a. Menegetahui kedudukan putusan ultra petita dalam pengujian undang-undang berdasarkan ketentuan normatif.

b. Menelaah pertimbangan (ratio decidendi) dibuatnya putusan Mahkamah Konstitusi yang mengandung ultra petita dalam pengujian undang-undang.

c. Menganalisis perspektif hukum progresif terhadap putusan ultra petita Mahkamah Konstitusi dalam pengujian undang-undang.

\section{A.4. Tinjuan Pustaka}




\section{a. Pemisahan Kekuasaan dan Chechk and Balances}

Spirit pemisahan kekuasaan dalam negara hukum adalah sebuah sebuah keniscayaan yang tak dapat dielakkan. Suatu negara yang telah menyatakan sebagai negara hukum, maka menurut konsepsinya pada negara tersebut harus melembagakan pemisahan kekuasaan, pembagian kekuasaan atau pembatasan keku-asaan. Namun yang terpenting dalam negara hukum sebenarnya adalah bahwa yang memerintah dalam negara bukanlah manusia, melainkan hukum, the rule of law and not of man.

\section{Black's Law}

Dictionary, mendefinisikan sepa-ration of powers

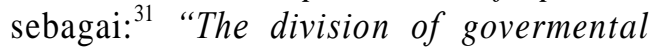
authority in to three branches of government -.- legislative, executive, and judicial --- each with specified duties on which neither of other brances can encroach; the constitutional doctrine of checks and balances by wich the people are protected againts tyranny.

Dalam teori pemisahan kekuasaan trias politica, masing-masing organ atau kekuasaan negara harus dipisah, oleh karena memusatkan lebih dari fungsi pada satu orang atau organ pemerintah akan membahayakan demikrasi dan kebebasan. Sebagian besar negara-negara didunia telah mengadopsi spirit teori pembatasan kekuasaan ini, namun tentu saja dengan corak dan modifikasi yang berbeda satu sama lain. Modifikasi ini antara lain terlihat dengan adanya ajaran pembagian kekuasaan dan ajaran check and balances system.

\footnotetext{
${ }^{31}$ Black's Law Dictionary, Seventh edition, West Group, St. Paul MINN, 1991, hal 1369-1370.
}

Setelah amandemen dilaku-kan terhadap UUD 1945, maka ada kecendrungan sistem yang digunakan dalam hubungan antar lembaga negara adalah faham pemisahan kekuasaan berdasarkan prinsip check and balances. Dalam ajaran check and balances lembaga-lembaga negara diakui saling setara dan sedrajat. Tidak ada lembaga negra yang sifatnya superior sebagaimana kedudukan Majelis Permusya-waratan Rakyat dahulu. Lembaga-lembaga Negara seperti MPR, DPR, DPD, Presiden, BPK, MA dan MK memiliki kedudukan yang sederajat, tidak ada yang ber-kedudukan lebih tinggi dari yang lain, namun prinsipnya lembagalembaga negara tersebut saling mengawasi dan mengendalikan satu sama lain. Inilah inti dari ajaran check and balances.

Perubahan ketiga UUD 1945 telah menciptakan sistem pemisahan kekuasaan yang memungkinkan adanya proses saling mengawasi dan saling mengimbangi di antara cabang-cabang kekuasaan negara. Hal itu tampak terutama dari salah satu kewenangan yang dilimpahkan kepada MK untuk menguji undang-undang terhadap Undang-Undang Dasar. ${ }^{32}$ Keberadaan MK dalam sistem ketatanegaraan Indonesia merupakan salah satu penunjang pelembagaan check and balances system tersebut.

\section{b. Tinjauan tentang Judicial Review}

\footnotetext{
${ }^{32}$ Maruarar Siahaan, Mengawal Konstitusionalitas Peraturan Perundang-Undangan Indonesia : Masalah dan Tantangan Dalam Sistem Hukum Kita, Makalah Center For Indonesian Constitutional Jurisprudence, tidak diterbitkan.
} 
Judicial review terdiri dari dua kata, yaitu "judicial" yang menunjukkan makna pengadilan dan kata "review", berarti memandang, menilai, menguji kembali. Secara sederhana judicial review dapat diartikan sebagai kewenangan untuk menguji oleh lembaga peradilan terhadap produk-produk hukum tertulis.

Pengujian yang dilakukan oleh Mahkamah Konstitusi berdasarkan UU Nomor 24 Tahun 2003 terbatas pada pengujian materiil dan pengujian formil (hal-hal diluar pengujian materiil) ${ }^{33}$. Dalam pengu-jian formil tercakup empat arti, yaitu: pertama, apakah bentuk peraturan perundang-undangan tersebut telah tepat atau belum, kedua apakah prosedur pembentukannya telah dilakukan secara tepat atau belum, ketiga, apakah lembaga pembentuk UU telah tepat atau belum, dan yang keempat adalah apakah format peraturan perundang-undangan tersebut telah benar atau tidak. Sedangkan dalam pengujian materiil ditekankan pada apakah materi dalam undang-undang yang diuji bertentangan atau tidak bertentangan UUD NRI Tahun 1945.

Dalam persepktif yang lebih luas, judicial review dapat diartikan kedalam tiga kategori, yaitu pertama: judicial review dalam arti luas, menyangkut semua pengujian norma hukum yang dilakukan oleh lembaga peradilan, apakah itu, keputusan, putusan pengadilan maupun peraturan perundang-undangan. Kedua judicial review dalam arti sempit, dalam hal pengujian norma hukumnya berupa peraturan perundang-undangan saja. Judicial review dalam arti sempit ini terbagi lagi dalam dua kelompok, yaitu:

\footnotetext{
${ }^{33}$ Pasal 51 ayat (3) UU Mahkamah Konstitusi
} 60 constitutional review jika yang diuji adalah UU terhadap UUD dan judicial review of regulations, jika yang diuji adalah peraturan perundang-undangan di bawah undang-undang terhadap undangundang. Fakus studi dalam penulisan hukum ini terbatas pada constitutional review, yaitu peng-ujian UU terhadap UUD.

Menurut Marshall, ${ }^{34}$ keberadaan lembaga judicial review dilandasi oleh beberapa alasan, yaitu: pertama, hakim bersumpah menjunjung tinggi konstitusi, sehingga jika ada peraturan yang bertentangan dengan konstitusi maka hakim harus melakukan pengujian terhadap peraturan tersebut. Kedua, konstitusi adalah the supreme of the land, sehingga harus ada peluang pengujian terhadap peraturan yang dibawahnya agar isi konstitusi tidak dilanggar. Ketiga, hakim tidak boleh menolak perkara, sehingga kalau ada yang mengajukan judicial review permintaan tersebut harus dipenuhi. Berdasarkan hasil penelitiannya Mahfud MD menambah satu alasan lagi mengapa judicial review penting bagi menjaga kosistensi politik hukum agar tetap pada rel konstitusi (politik konstitusi), yaitu bahwasanya hukum merupakan produk politik, sehingga oleh karenanya bisa saja undang-undang berisi hal-hal yang bertentangan dengan UUD atau konstitusi. ${ }^{35}$

Menurut Hans Kelsen, sebagai konsekuensi prinsip supremasi konstitusi

\footnotetext{
${ }^{34}$ Lihat Marshall dalam Mahfud MD, Perdebatan Hukum Tata Negara Pasca Amandemen, LP3ES, Jakarta, 2007, hal.96-97.

35 Mahfud MD, Membangun Politik Hukum Menegakkan Konstitusi, LP3ES, Jakarta, 1999, hal. 130.
} 
diperlukan adanya lembaga peradilan khusus yang berfungsi untuk menjaga kesesuaian antara hukum inferior dengan hukum yang superior, demikian seterusnya hingga berpuncak pada konstitusi. Kelsen $^{36}$ menjelaskan bahwa munculnya persoalan konflik antara norma yang lebih tinggi dengan yang lebih rendah bukan saja berkaitan antara undang-undang (statute) dan putusan pengadilan, tetapi juga berkaitan dengan hubungan antara konstitusi dan undang-undang. Dalam hal suatu undang-undang bertentangan dengan konstitusi, maka undang-undang tersebut adalah inkonstitusional.

\section{c. Putusan Mahkamah Konstitusi dan Masalah Ultra Petita}

Dari segi isinya, putusan Mahkamah Konstitusi dalam pengujian undang-undang terhadap Undang-Undang Dasar terdiri dari tiga jenis, antara lain: ${ }^{37}$

1) menyatakan permohonan tidak dapat diterima, apabila Mahkamah Konstitusi berpendapat bahwa pemohon dan/atau permohonannya tidak memenuhi syarat sebagaimana dimaksud dalam Pasal 50 dan Pasal 51.

2) menyatakan permohonan dikabulkan, apabila Mahkamah Konstitusi berpendapat bahwa permohonan beralasan. Dalam putusan tersebut Mahkamah Konstitusi harus dengan jelas menyatakan:

\footnotetext{
${ }^{36}$ Hans Kelsen, General Theory of Law and State, translated by: Anders Wedberg, Russell \& Russell, New York:, 1961. hlm. 97

37 Lihat Pasal 56 UU No.24 Tahun 2003 tentang Mahkamah Konstitusi
}

a. materi muatan ayat, pasal, dan/atau bagian mana dari undang-undang yang bertentangan dengan UndangUndang Dasar Negara Republik Indonesia Tahun 1945 dan menyatakan bahwa materi muatan ayat, pasal, dan/atau bagian undang-undang tersebut tidak mempunyai kekuatan hukum mengikat.

b. dalam hal pembentukan undangundang dimaksud tidak memenuhi ketentuan pembentukan undangundang berdasarkan Undang-Undang Dasar Negara Republik Indonesia Tahun 1945, amar putusan menyatakan permo-honan dikabulkan dan menyatakan undang-undang tersebut tidak mempunyai kekuatan hukum mengikat.

3) menyatakan permohonan ditolak, apabila undang-undang dimaksud tidak bertentangan dengan Undang-Undang Dasar Negara Republik Indonesia Tahun 1945, baik mengenai pembentukan maupun materinya sebagian atau keseluruhan.

Permasalahan muncul ketika Mahkamah Kostitusi membuat amar yang modelnya berbeda sebagai-mana amanat Pasal 56 junto Pasal 57 UU Mahkamah Konstitusi. Salah satu model amar tersebut adalah putusan mengandung ultra petita. 
Menurut I.P.M.Ranuhandoko, ${ }^{38}$ ultra petita diartikan sebagai melebihi yang diminta. Ultra petita merupakan terminologi yang cukup familier dalam hukum acara perdata. Dalam hukum acara perdata Indonesia dinormakan suatu asas yang membatasi hakim dalam memutus suatu perkara. Asas tersebut dituangkan dalam Pasal 178 ayat (2) dan (3) Reglemen Indonesia yang Di-perbaharui, yaitu: "Hakim itu wajib mengadili segala bahagian tuntutan." dan "Ia dilarang akan menjatuhkan keputusan atas perkara yang tidak dituntut, atau akan meluluskan lebih dari apa yang dituntut." Kriteria kapan seorang hakim dianggap ultra petita dapat ditentukan dengan dua batasan, yaitu: pertama, dalam hal hakim menjatuhkan putusan atas perkara yang tidak dituntut; dan kedua dalam hal hakim meluluskan atau mengabulkan lebih dari apa yang dituntut.

\section{d. Teori Hukum Progresif}

Hukum progresif pada prinsipnya bertolak dari dua komponen hukum, yaitu peraturan dan perilaku (rule and behavior). ${ }^{39}$ Satjipto Rahardjo menyatakan bahwa pemikiran hukum perlu kem-bali pada filosofis dasarnya, yaitu hukum untuk manusia ${ }^{40}$. Dengan filosofis

38 I.P.M. Ranuhandoko, Terminologi Hukum, Cetakan Kedua, Jakarta: Sinar Grafika, 2000, hlm.522.

39 Satjipto Rahardjo. "Menuju Produk Hukum Progresif". Makalah Diskusi Terbatas pada Fakultas Hukum UNDIP. Semarang, 24 Juni 2004

40 Satjipto Rahardjo, Hukum Progresif (Penjelajahan Suatu Gagasan), Makalah disampaikan pada acara Jumpa Alumni Program Doktor Ilmu Hukum Undip Semarang, tanggal 4 September 2004, hal. 3. tersebut, maka manusia menjadi penentu dan titik orientasi hukum. Hukum bertugas melayani manusia, bukan sebaliknya manusia melayani hukum. Berangkat dari asumsi ini, maka kehadiran hukum bukan untuk dirinya sendiri, melainkan untuk sesuatu yang lebih luas dan besar. Itulah sebabnya ketika terjadi permasalahan di dalam hukum, maka hukumlah yang harus ditinjau dan diperbaiki, bukan manusianya yang dipaksa untuk dimasukkan ke dalam skema hukum. ${ }^{41}$

Dalam perspektif teori hukum progresif, hukum itu bukan merupakan institusi yang otonom yang lepas dari kepentingan manusia. Mutu hukum ditentukan oleh kemampuannya untuk mengabdi pada kesejahteraan manusia. Hukum haruslah membahagiakan manusia. Konsep ini menyebabkan ajaran hukum progresif menganut ideologi hukum yang prokeadilan dan hukum yang prorakyat. Keadilan di atas hukum dan bukan sebaliknya. Jika aturan hukum tidak menampakkan nafas keadilannya, maka ia harus ditinggalkan.

Sudijono Sastroadmodjo ${ }^{42}$ memberikan ciri hukum progresif dari aspek kepeloporan aparat penegak hukum di bawah semboyannya "hukum untuk manusia" dan "keadilan di atas

41 Satjipto Rahardjo, Hukum Progresif. Hukum yang Membebaskan. Jurnal Hukum Progresif, Vol. 1/No. 1/April 2005, PDIH UNDIP, Semarang, hlm 5 .

${ }^{42}$ Sudijono, "Sedumuk Bathuk Sanyari Bumi" : Regulasi Tanah dan Demo Rakyat (Petani) dalam Menyoal Hak Atas Tanah, Makalah Pidato Pengukuhan Guru Besar Bidang Ilmu Hukum pada FIS Unnes, Semarang, 27 Desember 2006. hal. 57. 
peraturan”. Melalui semboyan ini, aparat penegak hukum dituntut untuk keluar dari pola kerja yang serba yuridis dan legalistik demi mewujudkan keadilan dan kebe-naran. Elemen-elemen utama dari model hukum progresif ini, yakni: pertama ideologi: pro rakyat, kedua, tujuan: pembebasan, ketiga, fungsi: pemberdayaan, keempat, jenis keadilan: keadilan sosial, kelima, metodologi : diskresi. $^{43}$ Pembebasan di sini di maksudkan sebagai pembebasan terhadap tipe, cara berpikir, asas, dan teori yang selama ini dipakai dan juga pembebasan terhadap kultur penegakkan hukum (administration of justice) yang selama ini berkuasa dan dirasakan menghambat hukum dalam menyelasaikan persoalan. ${ }^{44}$

\section{A.5. Metode Penelitian}

Penelitian hukum ini menggunakan metode pendekatan yuridis normatif dengan spesifikasi penelitian deskripsi analitis. Jenis data yang digunakan adalah jenis data skunder, terdiri dari bahan hukum primer, bahan hukum skunder dan bahan hukum tersier. Adapun teknik pengumpulan data yang digunakan menggunakan studi kepustakaan. Dari data-data yang terkumpul kemudian dianalisis secara kualitatif-normatif dengan jalan menafsirkan dan mengkontruksikan pernyataan yang terdapat dalam dokumen dan perundang-undangan.

\section{B. PEMBAHASAN}

\footnotetext{
${ }^{43}$ Sudijono, Konfigurasi Hukum Progresif, Jurnal Ilmu Hukum, FH Undip,Vol. 8, No.2, September 2005: 185-201.

${ }^{44}$ Satjipto Rhardjo, Hukum Progresif..... , Opcit, hal. 15-16.
}

\section{B.1. Sejarah Pelembagaan Judicial Review di Indonesia}

Mempelajari pelembagaan judicial review di Indonesia tidak akan lepas dari penelusuran bagaimana perjalanan gagasan ini pertama kali muncul dan berkembang hingga saat ini. Sampai saat ini telah ratusan negara yang melembagakan praktek consti-tutional review (judicial review) dalam sistem ketatanegaraanya. Indonesia sendiri merupakan negara ke-78 yang membentuk lembaga Mahkamah Konstitusi sebagai peradilan tata negara yang memiliki kewenangan untuk melakukan constitutional review dan merupakan negara pertama di dunia pada abad ke-21 yang membentuknya. ${ }^{45}$

Jika dirunut dari latar belakang sejarahnya, maka dari berbagai model pengujian $^{46}$ yang ada saat ini dapat diklasifikasikan dalam 2 jenis model utama, yaitu: decentralize model Amerika Serikat yang lebih dulu berkembang dan centralize model sebagaimana dipelopori

45 Uraian lengkap mengenai MK di 78 negara dapat dibaca dalam Jimly Asshiddiqie dan Mustafa Fakhri, Mahkamah Konstitusi, Kompilasi Ketentuan Konstitusi, UndangUndang dan Peraturan di 78 Negara, Jakarta: Pusat Studi HTN FH UI dan Asosiasi Pengajar HTN dan HAN Indonesia.

${ }^{46}$ Menurut Jimly, setidaknya terdapat 10 model pengujian konstitusional yang ada di berbagai negara, diantaranya adalah: Model Amerika Serikat, Model Austria (Continental Model), Model Dewan Konstitusi Prancis, Model Campuran Amerika dan Kontinental, Model Pengujian Special Chambers, Model Belgia, Model tanpa Judicial Review, Model Legislative Review, Model Executive Review, Model International Judicial Review. Lihat dalam Jimly Assiddiqie, 2005, Model-Model Pengujuan Konstitusional di Berbagai Negara, Konstitusi Press, Jakarta. hal 55-94. 
Austria yang lebih belakangan hadir. Model yang pertama mewakili gagasan yang dianut oleh negara-negara yang bertradisi common law dan model yang kedua diikuti oleh sebagian besar negaranegara Eropa yang bertradisikan civil law. Pada model Amerika Serikat, pengujian konsti-tusional dilakukan secara tersebar dan terdesentralisasi di antara pengadilan di negara-negara bagian dan Mahkamah Agung. Sedangkan pada model Austria atau model Eropa pengujian konstitusionalnya hanya dilakukan secara terpusat pada satu lembaga saja. Di samping itu menurut Jimly masih terdapat satu model lagi yang bersifat khas dan tidak dapat dikategorikan apakah mengikuti model Amerika Serikat atau Austria. Model tersebut adalah sebagaimana dipraktikkan di Prancis yang dilakukan oleh sebuah Dewan Konstitusi (Conseil de Constitutionel). Sebagaimana nama-nya, lembaga ini sesungguhnya bukanlah sebuah lembaga peradilan murni. ${ }^{47}$

Zainal Arifin Hoesein ${ }^{48}$ membagi tiga periode waktu terkait dengan perkembangan sistem judicial review di Indonesia. Pertama, masa awal penyusunan UUD 1945 hingga tahun 1970. Pada masa ini, judicial review hanyalah sebatas gagasan dan wacana yang tidak pernah terwujud; Kedua, masa saat mulai dirumuskannya UU Nomor 14 Tahun 1970 tentang Ketentuan-Ketentuan Pokok Kekuasaan Kehakiman hingga tahun 1999. Inilah kali pertama judicial review

\footnotetext{
${ }^{47}$ Ibid. hal 147.

48 Zainal Arifin Hoesein, 2009, Judicial Review di Mahkamah Agung: Tiga Dekade Pengujian Peraturan Perundang-Undangan, Rajagrafindo Persada, Jakarta.
}

dibahas secara mendalam dan diperdebatkan secara terbuka, sekaligus menjadi tonggak awal diterapkannya mekanisme tersebut; dan Ketiga, masa terjadinya perubahan UUD 1945 hingga tahun 2003. Dalam kurun waktu ini terjadi proses perubahan sistem politik dan kekuasaan negara, termasuk terbentuknya Mahkamah Konstitusi yang diberikan kewenangan untuk menguji undang-undang terhadap Undang-Undang Dasar 1945.

Pada saat pembahasan perubahan UUD 1945, gagasan mengenai pentingnya suatu peradilan tata negara muncul kembali, terlebih setelah MPR tidak lagi berkedudukan sebagai lembaga tertinggi negara. Prinsip supremasi parlemen yang selama ini dipegang kuat telah beralih dari supremasi MPR kepada supremasi konstitusi. ${ }^{49}$ Karena perubahan yang mendasar ini maka perlu disediakan sebuah mekanisme institusional dan konstitusional serta hadirnya lembaga negara yang mengatasi kemungkinan sengketa antar lembaga negara yang kini telah menjadi sederajat serta saling mengimbangi dan saling mengendalikan (checks and balances). ${ }^{50}$ Model pengujian kons-titusional sebagaimana dilembagakan di Austria yang tersentralisasi akhirnya menjadi pilihan MPR sebagai bentuk kelembagaan Mahkamah Konstitusi di Indonesia.

\footnotetext{
49 Lihat Pasal 1 ayat (2) UUD 1945: “Kedaulatan berada di tangan rakyat dan dilaksanakan menurut UUD"

50 Jimly A, Mahkamah Konstitusi Dalam Sistem Ketatanegaraan Republik Indonesia, Makalah pada Pendidikan Sespati dan Sespim Polri, Bandung, 19 April 2008.
} 


\section{B.2. Kedudukan Putusan Ultra Petita Dalam Pengujian UU Berdasarkan Ketentuan Normatif} Berbagai pihak memiliki pandangan yang saling bertentangan menanggapi putusan ultra petita yang dibuat oleh Mahkamah Konstitusi. Pihak yang pro terhadap putusan ultra petita berpandangan sebagai berikut:

- jika bagian dari yang dimohonkan review terkait dengan pasal-pasal lain dan menjadi jantung dari undangundang yang harus diuji, maka pembatalan pasal-pasal terkait tidak dapat dihindarkan;

- jika pemohon mencantumkan permohonan ex aequo et bono (memutus demi keadilan), maka hakim memiliki kebebasan untuk menentukan amarnya;

- doktrin larangan ultra petita hanya digunakan dalam hukum acara perdata;

- objektum litis dalam perkara perdata adalah hak-hak keperdataan, sedangkan dalam pengujiaan UU adalah hak konstitusional, karenanya ber-sifat erga omnes. Hak-hak keperdataan tidaklah dapat disamakan dengan hak konsti-tusional;

- kewenangan MK adalah menguji undang-undang terhadap UUD, jadi bukan pasal-pasal dan ayatnya;

- putusan ultra petita lazim di negaranegara lain, bahkan ide judicial review pertama kali bersal dari putusan Jhon Adam yang sangat ultra petita, dan
- UU Mahkamah Konstitusi tidak melarang secara tegas larangan melakukan ultra petita.

Di pihak lain, mereka yang menentang adanya putusan ultra petita di Mahkamah Konstitusi berpandangan bahwasanya putusan ultra petita dalam pengujian UU melanggar doktrin yang berlaku umum dan universal dalam hukum acara (larangan ultra petita), asas non ultra petita merupakan yurisprudensi internasional. Putusan ultra petita juga dianggap menciderai prinsip kedaulatan rakyat (supremasi parlemen), bahkan terkesan mencampuri ranah kekuasaan lain, sehingga melanggar doktrin pemisahan kekuasaan dan check and balances. Putusan ultra petita merupakan pelanggaran atas ranah legislatif oleh lembaga yudikatif karena mencampuri kewe-nangan mengatur (regeling) yang tidak dipersoalkan oleh pemohon. ${ }^{51}$ Terlebih lagi, dilakukannya ultra petita dianggap telah melanggar UU MK, karena UU MK tidak mengatur diperbolehkannya membuat putusan yang mengandung ultra petita. Dalam perspektif positivistiklegalistik, format amar putusan sebagaimana diatur dalam UU MK tidak memungkinkan adanya bentuk amar ultra petita.

Berdasarkan pada perbedaan perspektif menegenai ultra petita di atas, maka menurut hemat penulis terdapat dua permasalahan yang yang patut dielaborasi lebih lanjut guna menjawab bagaimana ke-dudukan vonis ultra petita dalam perspektif normatifnya. Pertama terkait dengan apakah doktrin ultra petita memang berlaku umum sehingga menjadi

${ }^{51}$ Mahfud MD, Mendudukkan...Op.cit. 
norma yang mengikat bagi semua hakim dalam berbagai perkara, dan kedua, mengingat UU MK tidak mengatur secara tegas, maka akan ditelaah secara komperhensif perihal bagaimanakah sesungguhnya perspektif UU MK terhadap vonnis ultra petita.

Untuk menganalisa kedua sub permasalahan di atas, akan digunakan 2 (dua) analisa pendekatan, yaitu analisa normatif dan analisa komparatif. Analisa nor-matif di sini akan digunakan untuk menelaah pasal-pasal dalam UU MK maupun Peraturan-Peraturan MK yang mengatur tentang Pengujian UndangUndang. Sedangkan analisa komparatif dalam pembahasan ini hanya dibatasi pada perbandingan antar sistem peradilan menurut hukum positif Indonesia, dalam hal ini hanya akan disajikan perspektifperspektif Hukum Acara Perdata, Hukum Acara Pidana, Hukum Acara PTUN terhadap putusan-putusan yang mengandung ultra petita. Dengan begitu, maka akan jelaslah kedudukan vonnis ultra petita, baik dalam perspektif sistem peradilan Indonesia pada umumnya dan pengujian undang-undang khususnya.

Ketentuan larangan ultra petita secara tegas diatur dalam pasal 178 ayat (3) Het Herziene Indonesisch Reglement, yang dalam hal ini dapat dimaknai dalam dua aspek, pertama, hakim dilarang untuk mengabulkan atas hal-hal yang tidak diminta oleh penggugat, dan kedua, hakim dilarang untuk mengabulkan lebih dari yang diminta oleh penggugat. Namun dalam perkembangan praktik peradilan, ketentuan larangan ultra petita ini tidak dianggap berlaku mutlak lagi berdasarkan yuris-prudensi Mahkamah Agung perkara Nomor 556K/Sip/1971 yang memberikan kaidah hukum bahwasanya mengabulkan lebih dari yang digugat adalah diizinkan selama hal itu masih sesuai dengan keadaan materiil.

Dalam hukum acara pidana larangan ultra petita hanya terkait dengan surat dakwaan yang sifatnya litis contestatio bagi pemeriksaan persidangan, dan sebaliknya tidak berlaku dalam kaitannya dengan tuntutan pidana. Sebelum berlakunya KUHAP, berdasarkan Yurisprudensi Mahkamah Agung dalam Putusan Nomor:47 K/Kr/1956 tanggal 23 Maret 1957, didapatkan kaidah hukum, bahwa yang menjadi dasar pemeriksaan oleh pengadilan ialah surat tuduhan (dakwaan), bukan tuduhan yang dibuat oleh polisi. Jadi, kedua pasal tersebut menegaskan bahwa putusan hakim hanya boleh mengenai fakta-fakta dalam batasbatas surat dakwaan jaksa penuntut umum.

Hakim tidak dibenarkan menjatuhkan hukuman diluar batas-batas yang terdapat dalam surat dakwaan, oleh sebab itu terdakwa hanya dapat dipidana berdasarkan apa yang terbukti mengenai kejahatan yang dilakukannya menurut rumusan surat dakwaan. Pasal 193 ayat (1) KUHAP memberikan batasan dengan tegas, "jika pengadilan berpendapat bahwa terdakwa bersalah melakukan tindak pidana yang didakwakan_kepadanya, maka pengadilan menjatuhkan pidana." Begitu juga sebaliknya, menurut Pasal 191 ayat (1) KUHAP, “jika pengadilan berpendapat bahwa dari hasil pemeriksaan di sidang, kesalahan terdakwa atas perbuatan yang didakwakan kepadanya tidak terbukti secara sah dan meyakinkan, maka terdakwa diputus bebas". 
Dalam hukum acara PTUN, meskipun secara normatif muatan ultra petita dilarang oleh karena menurut UU MA dapat dijadikan sebagai alasan mengajukan peninjauan kembali, akan tetapi dalam perkembangannya amar reformatio in peius diperkenankan. Reformatio in peius merupakan diktum putusan yang justru tidak menguntungkan penggugat. Contoh penerapan reformatio in peius misalnya dalam kasus kepegawain.

Melalui putusan MARI Nomor 5 K/TUN/1992, diputus tanggal 6 Pebruari 1993, hakim kasasi membuat kaidah hukum baru mengenai larangan ultra petita, sebagai berikut: "52“bahwa walaupun Penggugat asal tidak mengajukan dalam petitum, Mahkamah Agung dapat mempertimbangkan dan mengadili semua keputusan atau penetapan-penetapan yang bertentangan dengan tatanan yang ada. Adalah tidak pada tempatnya bila hak menguji Hakim hanya pada objek sengketa yang diajukan oleh para pihak karena sering objek sengketa tersebut harus dinilai dan sipertimbangkan dalam kaitannya dengan bagian-bagian penetapan-penetapan atau keputusan Badan atau Pejabat TUN yang tidak dipersengketakan antara kedua belah pihak (ultra petita).”

Berdasarkan pada uraian di atas, dapat dikatakan bahwasanya ketentuan larangan ultra petita bukanlah doktrin yang berlaku mutlak dan umum serta mengikat semua hakim dalam berbagai peradilan. Hal ini terjadi karena masingma-sing hukum acara memiliki karak-

52 Himpunan Kaidah Hukum Putusan Perkara Dalam Buku Yurisprudensi MA RI Tahun 19691997, Mahkamah Agung RI, 1999. hal. 10. teristik yang berbeda satu sama lain, disamping karena adanya kebutuhan perkembangan hukum dalam praktik peradilan. Kesimpulan ini juga kiranya berlaku dalam hukum acara pengujian undang-undang di Mahkamah Konstitusi. Namun untuk itu perlu dilihat sejauh mana ketentuannya dalam UU MK maupun Peraturan MK.

Putusan Mahkamah Konstitusi diambil setelah mempertimbangkan permohonan yang terdiri dari bagian posita atau uraian yang menjadi dasar permohonan dan petitum berdasarkan alat bukti yang ada. ${ }^{53}$ Jika permohonan dalam pe-ngujian materiil beralasan dan oleh karenanya dikabulkan, maka berdasarkan ketantuan Pasal 56 dan Pasal 57 UU MK, Mahkamah Konstitusi menyatakan bahwa materi muatan ayat, pasal, dan/atau bagian undang-undang bertentangan dengan Undang-Undang Dasar. Tidak ada bentuk amar lain selain amar yang didasarkan pada ketentu-an Pasal 56 dan Pasal 57 UU MK junto Pasal 36 huruf c Peraturan Mahkamah Konstutusi Nomor 6/PMK/2005. Dengan kata lain, dalam perspektif normatifnya, tidak ada ruang bagi hakim konstitusi untuk membuat amar yang mengandung ultra petita, terlebih yang mengandung positive legislature. Meskipun tidak diatur secara tegas, dalam arti tidak melarang secara tegas, akan tetapi dengan pendekatan penafsiran sistemik dapat di-simpulkan bahwasanya ketentuan-ketentuan dalam UU Nomor 24 Tahun 2003 tentang Mahkamah Konstitusi dan Peraturan MK Nomor 006/PMK/2005 tidak memungkin dibuatnya putusan yang mengandung ultra petita. Singkatnya, secara formatif,

53 Maruarar Siahaan, Op.cit. hal. 394. 
hukum acara peng-ujian undang-undang tidak memungkinkan dibuatnya putusan ultra petita.

Namun demikian dalam pratik telah ada beberapa putusan MK yang mengandung muatan ultra petita dan oleh karenanya dapat digunakan sebagai yurisprudensi MK. Yurisprudensi sendiri merupakan salah satu sumber hukum formal dalam hukum acara pengujian undangundang. Jika pemahaman terhadap yurisprudensi ini dikaitkan dengan boleh tidaknya melakukan ultra petita bagi hakim konstitusi, maka harus ada ketentuan dan kaidah tetapnya, apa dan sampai sejauh manakah batas-batas diperbolehkannya hakim konstitusi untuk membuat putusan yang mengandung ultra petita.

\section{B.3. Pertimbangan (Ratio Deci-dendi) dibuatnya Putusan MK yang Mengandung Ultra Petita dalam Pengujian Undang-Undang}

Beberapa putusan MK yang mengadung muatan ultra petita menjadi perdebatan dan kontroversi dikalangan ahli hukum, tidak hanya terkait dengan tindakan mengeluar-kan variasi putusan yang tidak ada dasar hukumnya, melainkan juga dampak putusan tersebut bagi penyelenggaraan negara dan penegakan hukum di Indonesia. Terlepas dari kontroversi tesebut, akan lebih baik kiranya jika ditelaah, apa sebenarnya yang mendorong dan me-latar belakangi para hakim konstitusi untuk mengeluarkan putusan ultra petita. Melalui pertimbangan hukum putusan kita akan menemukan penalaran hukum hakim, termasuk paradigma yang melandasi amar putusan yang dijatuhkan. Dengan begitu akan menjadi terang untuk dimengerti apa yang sebenarnya ingin dicapai/dituju oleh para hakim melalui putusannya. Dalam konteks pembahasan mengenai ultra petita ini, kita bisa mendapatkan kaidah hukum, sehingga oleh karenanya dapat ditentukan batas-batas sejauhmana ultra petita dapat dilakukan oleh Mahkamah Konstitusi dalam pengujian undangundang. Di bawah ini akan disajikan beberapa perkara tersebut:

\section{- Perkara Nomor 001-021-022/PUU- I/2003}

Dalam perkara Nomor 001-021022/PUU-I/2003, Mahkamah Konstitusi telah membatalkan Undang-Undang Nomor 20 Tahun 2002 tentang Ketenagalistrikan secara keseluruhan. Mahkamah Kon-stitusi dalam pertimbangan hukumnya sebenarnya lebih memfokuskan pengujiannya pada Pasal 16, Pasal 17 ayat (3), serta Pasal 68 UU Ketenagalistrikan yang memerintahkan sistem pemisahan/pemecahan usaha ketenagalistrikan (unbundling system) dengan pelaku usaha yang berbeda, akan tetapi karena pasalpasal tersebut merupakan pasal jantung dan paradigma yang mendasari UU Ketenaga-listrikan, maka keseluruhan UU Ketenagalistrikan dinyatakan tidak berkekuatan hukum mengikat. Mahkamah berpendapat bahwasanya sistem tersebut bertentangan dengan Pasal 33 UUD 45, karena dipandang akan semakin membuat terpuruk BUMN yang akan bermuara kepada tidak terjaminnya pasokan listrik kepada semua lapisan masyarakat, baik 
yang bersifat komersial maupun non komersial. $^{54}$

\section{- Perkara Nomor 007/PUU-III/2005}

Dalam pengujian UU No. 40 Tahun 2004 tentang Sistem Jaminan Sosial Nasional, Pemohon meminta agar Pasal 5 ayat (1), ayat (3) dan ayat (4) dan Pasal 52 dinyatakan bertentangan dengan Pasal 34 ayat (2) UUD 45 dan dinyatakan tidak berkekuatan hukum mengikat. Fokusnya utama dalam permohonan ini adalah, apakah pemaknaan negara dalam frasa "Negara mengembangkan sistem jaminan sosial...." berada di tangan Pemerintah Pusat, Pemerintahan Daerah ataukah kedua-duanya. Dalam amar putusannya, MK menolak permohonan pengujian Pasal 5 ayat (1) dan Pasal 52 UU SJSN, akan tetapi menetapkan Pasal 5 ayat (2) UU SJSN bertentangan dengan UUD Tahun 1945 dan menyatakan pasal tersebut tidak me-miliki kekuatan hukum mengikat, padahal para Pemohon tidak memintanya dalam permohonan. Dalam pertimbangan hukum terkait dengan ultra petita Pasal 5 ayat $(2)^{55}$ tersebut, Mahkamah Konstitusi menyatakan, bahwa meskipun tidak dimohonkan dalam petitum permohonan, namun ayat ini merupakan satu kesatuan yang tidak dapat dipisahkan dengan ayat (3), karenanya jika tetap dipertahankan malah akan menimbulkan multitafsir dan ketidakpastian hukum.

\section{- Perkara Nomor 003/PUU-IV/2006}

\footnotetext{
54 Putusan Nomor 001-021-022/PUU-I/2003, halaman 347.

55 Pasal 5 ayat (2) berbunyi: "Sejak berlakunya undang-undang ini, badan penyelenggara jaminan sosial yang ada dinyatakan sebagai Badan Penyelenggara Jaminan Sosial menurut undang-undang ini"
}

Putusan Nomor 003/PUU-IV/2006 merupakan putusan tentang pengujian Undang-Undang Nomor 31 Tahun 1999 (UU Tipikor). Isu utama yang nampak dalam putusan ini adalah dianulirnya ketentuan perluasan unsur "sifat melawan hukum materiil" sebagaimana dirumuskan dalam Penjelasan Pasal 2 ayat (1) UU PTKP. Dalam putusan tersebut Mahkamah Konstitusi secara jelas menyatakan bahwa permohonan uji materi atas kata "dapat" dan "percobaan" sebagai pokok petitum ${ }^{56}$ dinyatakan ditolak. Akan tetapi di lain pihak MK menetapkan bahwasanya Penjelasan Pasal 2 ayat (1) UU Tipikor dianggap telah memperluas kategori unsur "melawan hukum" dalam arti hukum tertulis (formele wederrechtelijk), melainkan juga dalam arti materiele wederrech-telijkheid (sifat melawan hukum materiil), dan karenanya bertentangan dangan 28D ayat (1) UUD 45. Menurut MK, Penjelasan suatu undang-undang tidak boleh memuat norma baru, karena penjelasan hanya memuat uraian atau jabaran lebih lanjut norma yang diatur dalam batang tubuh. Diakuinya ajaran sifat melawan hukum materiil dalam Pasal 2 ayat (1) juga akan menimbulkan permasalahan hukum, karena apa yang patut dan yang memenuhi syarat moralitas dan rasa keadilan yang diakui dalam masyarakat, yang berbeda-beda dari satu daerah ke daerah

56 Dalam permohonannya Dawud Jatmiko mendalilkan bahwasanya ketentuan dalam Pasal 2 ayat (1), Penjelasan Pasal 2 ayat (1), Pasal 3, Penjelasan Pasal 3, dan Pasal 15 (sepanjang mengenai kata "percobaan" dan "dapat") UU PTPK secara nyata telah bertentangan terhadap Pasal 28D ayat (1) UUD 45 
lain, akan mengakibatkan ketidakpastian hukum. ${ }^{57}$ Putusan ini tidak memberikan penjelasan yang terkait langsung dengan mengapa MK melakukan ultra petita, namun masuknya isu hukum sifat melawan hukum materiil ini dipengaruhi oleh pendapat Andi Hamzah dalam kapasitasnya sebagai ahli yang dihadirkan di persidangan. ${ }^{58}$

\section{- Perkara Nomor 005/PUU-IV/2006}

Putusan Nomor 005/PUU-IV/2006 merupakan putusan peng-ujian UndangUndang Nomor Nomor 22 Tahun 2004 tentang Komisi Yudisial (UU KY) dan Undang-undang Republik Indonesia Nomor 4 Tahun 2004 tentang Kekuasaan Kehakiman (UU KK) terhadap UUD 1945. Isu utama yang didengungkan dalam putusan ini adalah ketidakjelasan mekanisme pengawasan hakim dalam UU KY sehingga karenanya menimbulkan ketidakpastian hukum. ${ }^{59}$

Dalam Putusan ini setidaknya dapat ditemukan 2 (dua) muatan ultra petita. Pertama, terkait dengan dikeluarkannya perilaku hakim MK dari obyek pengawasan KY. Kedua terkait dengan dikebirinya seluruh kewenangan KY dalam mengawasi hakim (termasuk hakim agung dan hakim konstitusi). Hal ini terjadi karena permohonan para pemohon lebih terkait dengan keinginan agar hakim agung tidak dimasukkan sebagai pihak yang diawasi oleh KY, akan tetapi MK malah menganulir semua ketentuan yang

\footnotetext{
57 Putusan Nomor 003/PUU-IV/2006. Lihat halaman 74.

58 Lihat keterangannya dalam Putusan Nomor 003/PUU-IV/2006, halaman 67.

59 Mahkamah Konstitusi Republik Indonesia : Laporan Tahunan 2006, halaman 33.
}

terkait dengan pengawasan KY untuk mengawasi hakim. ${ }^{60}$

MK dalam pertimbangan hukumnya menyatakan bahwa "Pengecualian ini (Hakim MK) didasarkan oleh pemahaman sistematis dan penafsiran berdasarkan "original intent" perumusan ketentuan mengenai KY dalam Pasal 24B UUD 1945 memang tidak berkaitan dengan ketentuan mengenai MK yang diatur dalam Pasal 24C UUD 1945."61

Terkait dengan pembatalan seluruh kewenangan pengawasan, MK menganggap "bahwa pelaksanaan fungsi pengawasan yang lahir dari ketidakpastian hukum (rechtsonzekerheid) sebagai akibat tidak adanya norma yang jelas tentang ruang lingkup pengertian perilaku hakim dan pengawasan teknis justisial terkait dengan batas-batas akuntabilitas dari perspektif perilaku hakim dengan kemandirian hakim dalam melaksanakan tugas justisialnya, secara kasat mata merupakan intervensi terhadap kekuasaan kehakiman berupa pressure atau tekanan yang bersifat langsung atau tidak langsung”. ${ }^{6}$

\section{- Perkara Nomor 006/PUU-IV/2006}

Putusan dalam perkara 006/PUUIV/2006 yang membatalkan UndangUndang Nomor 27 Tahun 2004 tentang Komisi Kebenaran dan Rekonsilisas (UU KKR) secara keseluruhan sangat mengejutkan banyak pihak. Para Pemohon dalam permohonannya mendalilkan

\footnotetext{
${ }^{60}$ Bandingkan dengan Miftahul Huda, Ultra Petita Dalam Pengujian Undang-Undang, Artikel dimuat dalam Jurnal Konstitusi Mahkamah Konstitusi, vol. 4 No 3 (September 2007).

61 Putusan Nomor 005/PUU-IV/2005, Bagian Pertimbangan Hukum, halaman 173-174.

62 Ibid. halaman 201.
} 
bahwasanya keberadaan Pasal 1 angka 9, Pasal $27^{63}$ dan Pasal 44 bertentangan dengan UUD 45, khususnya Pasal 27 ayat (1), 28D ayat (1), 28I ayat (2). Menurut para Pemohon, norma dalam Pasal 27 UU KKR telah menegasikan jaminan atas anti diskriminasi, persamaan di depan hukum dan penghormatan martabat manusia yang dijamin oleh UUD $1945 .{ }^{64}$ Ditambah lagi, keberadaan Pasal 44 UU KKR dianggap akan menghilangkan kewajiban negara untuk menuntut dan menghukum pelaku. Dalam putusan tersebut, yang dinyatakan bertentangan dengan UUD 1945 sesungguhnya adalah Pasal 27 UU KKR, namun karena MK menganggap ketentuan pasal 27 menentukan operasionalisasi keseluruhan UU KKR, maka seluruh UU KKR dinyatakan tidak memiliki kekuatan hukum mengikat. Menurut MK, penentuan adanya amnesti sebagai syarat dipenuhinya kompensasi dan rehabilitasi merupakan hal yang mengesampingkan perlindungan hukum dan keadilan yang dijamin oleh UUD 1945.

\section{- Perkara Nomor 012-016-019/PUU- IV/2006}

Putusan MK dalam perkara Nomor 012-016-019/PUU-IV/2006 mengamanatkan sebuah pesan bahwa, adanya dualisme pengadilan yang mengadili tindak pidana korupsi (sebagaimana diformulasikan dalam Pasal 53 Undang-Undang Nomor 30 Tahun 2002 tentang Komisi Pemberantasan Tindak Pidana Korupsi) adalah

63 Pasal 27 UUKKR menyatakan bahwa : "Kompensasi dan rehabilitasi sebagaimana dimaksud dalam Pasal 19 dapat diberikan apabila permohonan amnesti dikabulkan."

${ }^{64}$ Lihat Putusan Nomor 006/PUU-IV/2006, Bagian duduk perkara (uraian permohonan) halaman 21. bertentangan dengan UUD 1945, oleh karena itu diperlukan penyempurnaan pengaturan pengadilan tindak pidana korupsi dalam sistem peradilan Indonesia. Menjadi terlihat unik karena dalam amarnya MK menunda keberlakuan mengikatnya putusan dan memberikan batas waktu 3 (tiga) tahun bagi pihak legislator untuk membentuk Undang-Undang Pengadilan Tipikor. Suatu amar penundaan yang sebenarnya sama sekali tidak dimintakan oleh para pemohon. Mahkamah Konstitusi mendalilkan, bahwa meskipun Pasal 47 UU MK menyatakan bahwa "Putusan Mahkamah Konstitusi memperoleh kekuatan hukum tetap sejak selesai diucapkan dalam sidang pleno terbuka untuk umum"; akan tetapi agar pemeriksaan tindak pidana korupsi oleh KPK dan Pengadilan Tipikor yang sedang berjalan tidak terganggu dan tidak mengalami kekacauan sehingga dapat menimbulkan ketidakpastian hukum yang tidak dikehendaki oleh UUD 1945, maka MK mempertimbangkan perlunya menyediakan waktu bagi proses peralihan yang mulus (smooth transition) untuk terbentuknya aturan yang baru. ${ }^{65} \mathrm{Di}$ sinilah sikap kenegarawanan dan kearifan para hakim, sangat dinampakkan. Terobosan-terobosan seperti ini mengandung nilai kemanfaatan dan keadilan sekaligus bertujuan untuk mewujudkan kepastian hukum.

Dari sebagian kasus ultra petita yang disajikan di atas, jika dibuat pengelompokan pertimbangan yang dipakai oleh hakim konstitusi, maka akan didapatkan data-data terkait dengan mengapa hakim konstitusi membuat putusan yang ultra petita, sebagai berikut:

65 Ibid. hal. 286. 
- Bagian dari undang-undang (ayat, pasal, penjelasan, dsb) yang diminta diuji merupakan "jantung" dari undang-undang, sehingga seluruh pasal tidak dapat dilaksanakan dan harus dinyatakan tidak berkekuatan hukum mengikat seluruhnya. Termasuk dalam kategori ini misalnya: Pembatalan UU Ketenagalistrikan (Perkara Nomor: 001-021-022/PUU-I/2003) dan Pembatalan UU Komisi Kebenaran dan Rekonsiliasi (Perkara Nomor 006/ PUU- IV/2006).

- Bagian dari undang-undang (ayat, pasal, penjelasan, dsb) yang diminta diuji berkaitan dengan pasal-pasal lainnya yang tidak dapat dipisahkan, sehingga pasal yang berkaitan tersebut akhirnya dinyatakan tidak berkekuatan hukum juga. Termasuk dalam kategori pertimbangan ini adalah : Pengujian UU Sistem Sistem Jaminan Sosial Nasional (Perkara Nomor 007/PUU-III/ 2005). Dalam Pengujian UU Komisi Yudisial (Perkara Nomor 005/PUU-IV/2006) nampaknya juga mengarah pada pertimbangan ini, meskipun MK tidak menguraikannya secara tegas.

- Demi menghindari kekacauan hukum, maka ditempuh penundaan keberlakuan mengikatnya putusan sambil menunggu dibentuknya aturan perbahan yang baru. Dalam hal ini, alasan kemanfaatan mengalahkan kepastian hukum, meskipun sesungguhnya tujuan akhirnya juga untuk men- ciptakan kepastian hukum. Termasuk dalam kategori alasan ini adalah putusan pembatalan dasar hukum Pengadilan Tipikor (Perkara Nomor 012-016-019/PUU-IV/2006). Putusan MK yang menguji Undang-Undang Nomor 16 Tahun 2008 tentang Perubahan Atas Undang-Undang Nomor 45 Tahun 2007 tentang APBN Tahun Anggaran 2008 (Perkara Nomor 04/PUU-VI/2008) juga masuk dalam kategori alasan ini.

- Pertimbangan hukum MK dalam masalah ultra petita hanya dikaitkan dengan pertimbangan hub kum pokok permohonan, bahkan tak jarang terkesan mengada-ada dan muncul secara tiba-tiba. Dalam kategori inilah pernyataan Harjono ${ }^{66}$ menjadi relevan, bahwa menurut UUD sangatlah jelas, kewenangan MK adalah menguji undang-undang terhadap UUD, jadi bukan pasal-pasal dan ayatnya. Sepanjang yang diuji adalah undangundang terkait, maka tidak ada kamus ultra petita. Termasuk dalam kategori ini adalah dalam perkara pembatalan sifat melawan hukum materiil dalam UU Tipikor (Perkara Nomor 003/PUUIV/ 2006) dan perkara Nomor 005/ PUU-IV/2006 yang memangkas Kewenangan Komisi Yudisial, sepanjang terkait dengan dikeluarkannya hakim Mahkamah

\footnotetext{
${ }^{66}$ Harjono, Op.cit. hal. 182-185.
} 
Konstitusi dari pihak yang diawasi Komisi Yudisial.

\section{B.4. Ultra Petita Dalam Pengujian Undang-Undang : Perspektif Hukum Progresif}

Kegamangan teks yang mengatur jenis dan muatan yang harus ada dalam putusan Mahkamah Konstitusi menjadikan perdebatan yang sampai saat ini belum berujung. Sebagai salah satu dampaknya, putusan ultra petita Mahkamah Konstitusi dalam pengujian undang-undang juga menjadi kontroversi di sana-sini. Pihak yang pro menganggap bahwasanya hukum acara Mahkamah Konstitusi (MK) tidak mengatur ultra petita, karena itu boleh saja MK membuat putusan yang bersifat ultra petita. Logika hukum ultra petita hanya ada dalam hukum acara perdata, karena objectum litis di MK berbeda dengan peradilan perdata yang melindungi orangperorangan, sedangkan di MK lebih bersifat hukum publik, tidak hanya melindungi kepentingan pihak-pihak yang berperkara, akan tetapi bersifat erga omnes. Berkaitan dengan belum diatur ketentuan hukum acara secara terperinci termasuk ultra petita, MK berhak mengatur penjabaran dalam PMK dan dalam perjalanan menemukan hukumnya dalam kekuasaan mengadili. ${ }^{67}$

Dibukanya preseden baru melalui putusan pertamanya dalam pengujian Undang-Undang Ketenagalistrikan menjadikan solusi pemecahan kebuntuan normatif yang melekat pada UU MK dan PMK Nomor 05/PMK/2005 terkait dengan

67 Miftahul Huda, Ultra Petita Dalam PengujianUndang-Undang, Jurnal Konstitusi vol 4 No 3 (September 2007) teka-teki larangan ultra petita. Putusan yang telah membatalkan ruh liberalisasi sektor ketenagalistrikan dalam UndangUndang Nomor 20 Tahun 2002 tentang Ketenagalistrikan telah menjadi penawar kekhawatiran masyarakat atas hak-hak konstitusional mereka yang berpotensi dilanggar oleh undang-undang tersebut. Meskipun ketentuan yang dipandang bertentangan dengan konstitusi pada dasarnya hanyalah Pasal 16, 17 ayat (3), serta 68, khususnya yang menyangkut unbundling dan kompetisi, akan tetapi karena pasal-pasal tersebut merupakan jantung dari UU Nomor 20 Tahun 2002, maka UU Ketenagalistrikan harus dibatalkan secara keseluruhan.

Meskipun peraturannya masih bersifat sumir dan multi tafsir, proses perubahan tidak harus selalu berpusat pada peraturan yang ada, akan tetapi pada kreatifitas pelaku hukum dalam kontektualitasnya. Dalam konteks kasus ini hakim MK telah berani melakukan kreatifitas dan terobosan-trobosan hukum dalam menjadikan atruan lebih bermakna dan fungsional bagi terciptanya keadilan. Mahkamah Konstitusi telah melakukan rule breaking dalam rangka memecah kekaburan (obscure) ketentuan dalam UU MK dan PMK untuk melahirkan embrioembrio jenis putusan baru yang bisa digunakan untuk mewujudkan keadilan subtantif di masa-masa pengujian yang akan datang. Inilah yang oleh Satjipto Rahardjo dikatakan bahwasanya hakikat hukum selalu dalam proses menjadi (law as a process in the law making). ${ }^{68}$

68 Satjipto Rahardjo, Hukum Progresif. Hukum yang Membebaskan. Jurnal Hukum Progresif, Vol. 1/No. 1/April 2005, PDIH UNDIP, Semarang,, halaman 6. 
Dengan demikian dapat dikatakan, preseden atas dibuatnya putusan yang mengandung ultra petita dalam hukum acara pengujian undang-undang tersebut dapatlah kita kategorikan sebagai tindakan penegakan hukum yang progresif. Akan tetapi, perlu digaris bawahi, bahwasanya kreatifitas apapun yang dilakukan oleh penegak hukum dapat menjadi tidak bermakna progresif manakala tidak untuk mewujudkan keadilan subtantif, menempatkan keadilan, kemanfaatan dan kebahagiaan manusia sebagai tujuan akhirnya. Dengan kata lain, bisa saja putusan-putusan yang mengandung ultra petita itu malah menciderai keadilan dan ke-manfaatan.

Dalam konteks putusan-putusan yang mengandung ultra petita sebagaimana telah diuraikan pada sub bab sebelumnya, dapat dikatakan bahwasanya tidak semua putusan-putusan tersebut menampakan sisi keadilan subtantif, dan karenanya pula tidak dapat disebut sebagai bentuk penegakan hukum yang progresif. Dalam putusan ultra petita pembatalan UU KKR (Perkara Nomor 006/PUU-IV/2006) misalnya, MK dianggap hanya menititikberatkan pada aspek yuridis semata. ${ }^{69}$ Putusan KKR juga telah membawa keresahan di kalangan korban, yang selama ini melihat keberadaan UU KKR sebagai satu harapan untuk mewujudkan keadilan atas apa yang mereka alami di masa lalu. ${ }^{70}$

${ }^{69}$ AM. Fatwa dalam Menimbang-Nimbang Kinerja Mahkamah Konstitusi, Berita Majalah Figur, Edisi X/Th. 2007.

${ }^{70}$ Indriaswaty D S, S.H, LLM, dkk, Ketika Prinsip Kepastian Hukum Menghakimi Konstitusionalitas Penyelesaian Pelanggaran Ham Masa Lalu Pandangan Kritis Atas Putusan
Perkara pemangkasan kewenangan KY (Perkara Nomor 005/PUU-IV/2006) yang memangkas Kewenangan Komisi Yudisial, terkait dengan dikeluarkannya hakim Mahkamah Konstitusi dari pihak yang diawasi Komisi Yudisial juga terlihat adanya sikap diskriminatif dan cenderung legalistik, karena hanya memperhatikan aspek original intens UUD 45 saja sebagai pertimbangan hukumnya. Itulah keadilan proseduralnya, karena memang benar pada saat pembahasan dalam PAH I MPR, sama sekali tidak muncul nama hakim konstitusi sebagai pihak yang perilakunya diawasi Komisi Yudisial. Secara historis fakta hukum tersebut memang tidak dapat ditolak, tapi apakah nuansa putusan MK di atas mencerminkan nilai keadilan dan kemanfaatan, terlebih apabila dikaitkan dengan pembatalan seluruh kewenangan KY dalam mengawasi hakim ditengahtengah benang kusut mafia peradilan.

Lain halnya dalam konteks pembatalan dasar hukum Pengadilan Tipikor (Perkara Nomor 012-016-019/PUUIV/2006). Menurut hemat penulis putusan ini menampakkan sisi progresifitas dalam penegakan hukum. MK dalam hal ini berusaha mempertemukan tiga nilai tujuan hukum, yakni: keadilan, kepastian dan kemanfaatan. Dari aspek keadilan, MK menganggap bahwasanya keberadaan pengadilan Tipikor menjadikan dualisme dan standar ganda bagi terdakwa dalam perkara tipikor. Pada aspek

MK dan Implikasinya Bagi Penyelesaian Pelanggaran HAM di Masa Lalu, Position Paper Elsam Terhadap Putusan MK Membatalkan UU KKR, Jakarta, 19 Desember 2006, diunduh dari laman http://www.elsam.or.id, pada tanggal 0601-2010. 
kepastian hukum, MK melihat bahwasanya secara formal terdapat kesalahan dalam landasan berdirinya Pengadilan Tipikor yang seharusnya dibuat dalam undang-undang tersendiri. Dari aspek kemanfaatan terlihat dari upaya MK untuk menghindari kekacauan hukum yang bisa ditimbulkan oleh karena dibatalkannyan dasar hukum Pengadilan Tipikor dengan memberikan tenggang waktu 3 (tiga) tahun bagi pihak legislaor untuk membentuk UU Pengadilan Tipikor.

Dengan demikian dapatlah dibuat suatu kesimpulan bahwasanya tidak semua putusan MK dalam pengujian undang-undang yang mengandung ultra petita mengandung ciri-ciri penegakan hukum yang progresif. Keberanian MK untuk berkreasi dalam putusanya memang baik, sepanjang tindakan tersebut digunakan sesuai konteks dan dalam rangka mewujudkan keadilan subtantif.

Tentu selalu ada pihak-pihak yang tidak puas terhadap tindakan-tindakan MK dalam membuat putusan dengan menerapkan prinsip rule breaking sebagaimana dalam putusan yang bersifat ultra petita dan bahkan positive legislature. Hal ini tidak terlepas dari mazhab dan paradigma pemikiran positivisme hukum yang memang menguasai sebagian besar praktisi dan akademisi hukum Indonesia. Kekhawatirankekhawatiran seperti ini tidak hanya terjadi di Indonesia, melainkan juga di beberapa negara yang memiliki sistem pengujian konstitusional. Dalam hal ini, Mahkamah Konstitusi RI juga telah memasuki wilayah yang dalam tradisi common law dikenal dengan judicial activism, suatu pemikiran hakim dalam putusan yang kadang-kadang terlihat liberalprogresif dalam pertimbangan hukum putusannya.

Namun demikian, praktik judicial activism yang cenderung judicative heavy justru dapat menjadi negatif dan destruktif jika digunakan untuk memelihara konservatisme lembaga peradilan atau memuluskan preferensi subyektif para elit maupun para hakim sendiri. Apabila itu terjadi, dengan kewenangan yang besar, lembaga yudikatif dapat bermetamorfosis menjadi lembaga yang otoriter (judicial authoritarian) yang justeru mengingkari prinsip dasar separation of power dan check and balances. Kekuasaan memang selalu menampakkan wajah aslinya untuk selalu cenderung menindas dan korup. Sebagaimana Lord Acton dengungkan, "power tends to corrupt, and absolut power corrupt absolutelly. Penggunaan judicial activism secara berlebihan justru dapat menyebabkan iklim yang tidak sehat bagi pertumbuhan demokrasi itu sendiri. Untuk menjaganya, maka aktivisme yudisial perlu selalu dikawal dengan kritisasi akademik yang konstruktif, sehingga pengadilan tidak akan kehilangan legitimasinya. $^{71}$

Berkaca pada realita penegakan hukum di atas, maka dapat pula ditawarkan gagasan pembatasan kekuasaan Mahkamah Konstitusi melalui perubahan progresif UU MK sebagai salah satu alternatif pembenahan sistem peradilan tata negara di Indonesia. Dalam perspektif hukum progresif sesungguhnya perubahan terhadap UU MK bukanlah sesuatu keharusan yang mutlak. Bagi hukum progresif, proses perubahan tidak

\footnotetext{
${ }^{71}$ Pan Mohamad Faiz, Konstitusi Dan Aktivisme Yudisial, Jurnal Nasional, Selasa, 25-08-2009.
} 
lagi berpusat pada peraturan, akan tetapi pada kreatifitas pelaku hukum dalam konteks dalam berbagai kasus yang ia tangani. Para pelaku hukum progresif dapat melakukan perubahan dengan melakukan pemaknaan yang kreatif terhadap peraturan yang ada tanpa menunggu perubahan peraturan. $^{72} \mathrm{Se}-$ baliknya, ajaran hukum progresif juga tidak menafikan sama sekali perihal pentingnya revisi suatu peraturan mana-kala memang terbukti tidak mendukung upaya penegakan hukum yang adil. Menurut Satjipto Rahardjo, hukum progresif selalu memiliki karakter peka terhadap perubahan yang terjadi di masyarakat, baik lokal, nasional maupun global. ${ }^{73}$ Berkaca pada realita penegakan hukum di atas, maka dapat pula ditawarkan gagasan pembatasan kekuasaan Mahkamah Konstitusi melalui perubahan progresif UU MK sebagai salah satu alternatif pembenahan sistem peradilan tata negara di Indonesia.

Dengan berlandaskan pada pemikiran hukum progresif, maka dibutuhkan rekonstruksi UU MK dengan pengaturan baru yang memberikan kewenangan bagi MK untuk membuat amar yang mengandung ultra petita, dalam arti tidak dibatasi secara restriktif atas bentuk dan isi amarnya, Kewenangan Mahkamah Konstitusi dalam membuat putusan ultra petita dilandasi oleh alasanalasan: pertama, dalam hal pasal yang diuji terdapat keterkaitan yang tidak terpisahkan dengan pasal-pasal lain yang tidak dimohonkan dalam undang-undang yang sama; kedua, dalam hal pasal yang

72 Bernard Tanya, Bernard L., dkk. Teori Hukum. Strategi Tertib Manusia Lintas Ruang dan Generasi, CV. KITA: Surabaya, 2006, hlm. 213.

$73 \mathrm{lbid}, \mathrm{hlm} .16-17$. diuji adalah pasal jantung atau ruhnya undang-undang, karenanya dengan dinyatakan tidak mengikatnya pasal tersebut undang-undang yang bersangkutan menjadi tidak dapat dilaksanakan atau mengalami kelumpuhan; ketiga, dengan landasan untuk mewujudkan kemanfaatan bagi rakyat dan demi menghindarkan dari kekacauan hukum di masyarakat; keempat, dengan landasan untuk mewujudkan keadilan subtantif dan menegakkan konstitusi; kelima, Mahkamah Konstitusi dibatasi tidak boleh membuat amar ultra petita diluar undangundang yang dimohonkan untuk diuji; dan keenam, amar putusan dimungkinkan berupa penafsiran norma pasal dalam bentuk konstitusional bersyarat atau ketidak-konstitusianal bersyarat.

\section{PENUTUP}

\section{C.1. Kesimpulan}

1. Ketentuan larangan ultra petita secara prinsip diatur dalam pasal 178 ayat (3) Het Herziene Indonesisch Reglement, yang dalam hal ini dapat dimaknai dalam dua aspek, pertama, hakim dilarang untuk mengabulkan atas halhal yang tidak diminta oleh penggugat, dan kedua, hakim dilarang untuk mengabulkan lebih dari yang diminta oleh penggugat. Meskipun UndangUndang MK tidak mengatur secara tegas perihal larangan ultra petita ini, akan tetapi dengan pendekatan penafsiran sistemik, dapat disimpulkan bahwasanya ketentuan-ketentuan dalam UU Nomor 24 Tahun 2003 tentang Mahkamah Konstitusi dan Peraturan 
MK Nomor 006/PMK/ 2005 (secara format) tidak memungkinkan bagi hakim konstitusi untuk membuat amar putusan yang mengandung ultra petita. Namun demikian dalam pratik telah ada beberapa putusan MK yang mengandung amar ultra petita dan oleh karenanya dapat digunakan sebagai sumber hukum yurisprudensi MK. Yurisprudensi sendiri merupakan salah satu sumber hukum formal dalam hukum acara pengujian undangundang. Ketentuan larangan ultra petita juga bukan doktrin yang berlaku umum dan mengikat semua hakim, dengan alasan sebagai berikut:

- Dalam perkembangannya, larangan ultra petita dalam hukum acara perdata tidaklah berlaku mutlak berdasarkan yurisprudensi MARI Nomor 556K/ Sip/1971 yang memberikan kaidah hukum bahwasanya mengabulkan lebih dari yang digugat adalah diizinkan selama hal itu masih sesuai dengan keadaan materiil.

- Dalam hukum acara pidana larangan ultra petita ini hanya terkait dengan surat dakwaan yang sifatnya litis contestatio bagi pemeriksaan persidangan, dan sebaliknya tidak berlaku dalam kaitannya dengan tuntutan pidana ;

- Dalam hukum acara PTUN, meskipun secara normatif muatan ultra petita dilarang karena menurut UU MA dapat dijadikan sebagai alasan mengajukan peninjauan kembali, akan tetapi dalam perkembangannya amar putusan reformatio in peius dimungkinkan untuk dijatuhkan.

2. Dalam beberapa putusannya, MK telah memutuskan melebihi dari yang dimohonkan (ultra petita). Diantara putusan-putusan tersebut adalah: Perkara Nomor 001-021-022/PUU-I/ 2003, Perkara Nomor 007/PUUIII/2005, Perkara Nomor 003/ PUUIV/2006, Perkara Nomor 005/PUUIV/2006, dibacakan Perkara Nomor 006/PUU-IV/ 2006, Perkara Nomor 012-016-019/PUU-IV/2006, Perkara No-mor 101/PUU-VII/2009, Perkara Nomor 11-14-21-126-136/PUU-VII/ 2009, dan lain sebagainya. Dari beberapa putusan yang dibahas tersebut dapat disimpulkan bahwasanya terdapat 4 kelompok pertimbangan hakim yang melandasi dibuatnya amar putusan ultra petita, di antaranya adalah:

- Bagian dari undang-undang (ayat, pasal, penjelasan, dsb.) yang diminta diuji merupakan "jantung" dari undang-undang, sehingga seluruh pasal tidak dapat dilaksanakan dan harus dinyatakan tidak berkekuatan hukum mengikat seluruhnya.

- Bagian dari undang-undang (ayat, pasal, penjelasan, dsb) yang diminta diuji berkaitan dengan pasal-pasal lainnya yang tidak 
dapat dipisahkan, sehingga pasal yang berkaitan tersebut akhirnya dinyatakan tidak berkekuatan hukum juga.

- Demi menghindari kekacauan hukum, maka ditempuh penundaan keberlakuan mengikatnya putusan sambil menunggu dibentuknya aturan perubahan yang baru.

- Pertimbangan hukum MK dalam masalah ultra petita hanya dikaitkan dengan pertimbangan hukum pokok permohonan, bahkan tidak jarang terkesan muncul secara tiba-tiba.

3. Meskipun pengaturan mengenai larangan ultra petita masih bersifat multi tafsir, namun dalam perspektif hukum progresif proses perubahan tidak harus selalu berpusat pada peraturan yang ada, akan tetapi pada kreatifitas pelaku hukum dalam konteksnya. Terobosan MK dalam membuat putusan ultra petita pada prinsipnya adalah bentuk dari penegakan hukum yang progresif. Dalam konteks putusan ultra petita yang menguji UU Ketenagalistrikan misalnya, hakim MK telah berani melakukan kreatifitas dan rule breaking dalam menjadikan aturan lebih bermakna dan fungsional bagi terciptanya keadilan. Akan tetapi, perlu digaris bawahi, bahwasanya kreatifitas apapun yang dilakukan oleh penegak hukum dapat menjadi tidak bermakna progresif manakala tidak untuk mewujudkan keadilan subtantif, menempatkan keadilan, kemanfaatan dan kebahagiaan manusia sebagai tujuan akhirnya. Karenanya, perubahan progresif atas UU MK menjadi salah satu alternatif bagi terwujudnya penegakan hukum yang progresif.

\section{C.2. Saran}

Berdasarkan pada pembahasan di atas, disarankan agar dilakukan perubahan terhadap Undang-Undang Mahkamah Konstitusi. Perubahan tersebut adalah sebagai upaya merekonstruksi UndangUndang Mahkamah Konstitusi yang didalamnya berisi ketentuan diperbolehkannya membuat amar putusan yang mengandung ultra petita, dengan ketentuan:

1. Dalam hal pasal yang diuji terdapat keterkaitan yang tidak terpisahkan dengan pasal-pasal lain yang tidak dimohonkan dalam undang-undang yang sama;

2. Dalam hal pasal yang diuji adalah pasal jantung atau ruhnya undangundang, karenanya dengan dinyatakan tidak mengikatnya pasal tersebut undang-undang yang bersangkutan menjadi tidak dapat dilaksanakan atau mengalami kelumpuhan;

3. Dengan landasan untuk mewujudkan kemanfaatan bagi rakyat dan demi menghindarkan dari kekacauan hukum di masyarakat; 
4. Dengan landasan untuk mewujudkan keadilan subtantif dan menegakkan konstitusi, serta

5. Mahkamah Konstitusi dibatasi tidak boleh membuat amar ultra petita diluar undang-undang yang dimohonkan diuji atau hanya sebatas undang-undang yang diuji saja.

\section{DAFTAR PUSTAKA}

Adnan Buyung Nasution dalam "Quo Vadis" Hukum dan Peradilan di Indonesia, Kompas Edisi 22 Desember 2006.

Alim, Muhammad, 2008, Trias Politika dalam Negara Madinah, Setjen MKRI, Jakarta.

Assiddiqie, Jimly. Gagasan Dasar Tentang Konstitusi dan Mahkamah Konstitusi, Makalah, di unduh dari www.jimli.com/makalah

---------,2008. Mahkamah Konstitusi dalam Sistem Ketatanegaraan RI, Bahan ceramah pada Pendidikan Sespati dan Sespim Polri, Bandung, 19 April 2008.

--------, 2005. Hukum Acara Pengujian Undang-Undang, Skretariat Jenderal dan Kepaniteraan MKRI, Jakarta.

2005. Sengketa Kewenangan antar Lembaga Negara, Konpress, Jakarta.

2005. Konstitusi dan Konstitusionalisme Indonesia, Skretariat Jenderal dan Kepaniteraan MKRI, Jakarta.
Fajar, Abdul Mukti. 2006. Hukum Konstitusi dan Mahkamah Konstitusi, Jakarta, Konstitusi Press. Citra Media.

Harjono, 2008, Konstitusi Sebagai Rumah Bangsa, Sekjen dan Kepaniteraan MKRI, Jakarta. 1961. General Theoy Of Law and Staat. Russell \& Russell. New York. diterjemahkan oleh Muttaqien, Raisul. 2006. Teori Umum tentang Hukum dan Negara, Cetakan I, Nusamedia dan Nuansa. Bandung.

2007. Teori Hukum Murni : Dasar-dasar Ilmu Hukum Normatif, Bandung, Nusamedia dan Nuansa.

KC. Wheare, Modern Constitution, London-New York-Toronto, Oxford University Press, 3rd Impression, 1975.

Levy, Leonard W. 2005. Judicial Review. Bandung. Nusamedia dan Nuansa.

Mahfud MD, Konstitusi dan Hukum dalam Perdebatan Isu, Rajawali Press, Jakarta, 2009. 
--------, 1999, Membangun Politik Miftahul Huda, Ultra Petita Dalam Hukum Menegakkan Konstitusi, LP3ES, Jakarta.

2007,Perdebatan Hukum Tata Negara Pasca Amandemen, LP3ES, Jakarta.

2008. Rambu Pembatas dan

Perluasan

Kewenangan

Mahkamah Konstitusi, disampaikan di depan Komisi III DPR-RI pada saat fit and proper test untuk menjadi hakim konstitusi tanggal 12 maret 2008.

2008. Kekuasaan Kehakiman Pasca Amandemen UUD 1945. Makalah pada diskusi publik tentang Wacana Amandemen Konstitusi yang diselenggarakan oleh Komisi Hukum Nasional (KHN) di Jakarta Tanggal 12 Juni 2008.

--------, 2007. Putusan Mahkamah Konstitusi Belum Tentu Benar dalam Harian Seputar Indonesia tanggal 14 Agustus 2007.

----- Politik Hukum Menuju
Pembangunan Sistem Hukum Nasional, Makalah disampaikan pada Seminar "Arah Pembangunan Hukum Menurut UUD 1945 Hasil Amandemen, yang diselenggarakan oleh BPHN Dephuk HAM RI, di Jakarta, pada tanggal 29-31 Mei 2006.
PengujianUndang-Undang, Jurnal Konstitusi vol 4 No 3 (September 2007).

Pan Muhammad Faiz, Mengawal Demokrasi Melalui

Constitutional Review:

Sembilan Pilar Demokrasi Putusan Mahkamah Konstitusi, Makalah dalam Buku "UI untuk Bangsa" Tahun 2009.

Rahardjo, Satjipto. 2004. Makalah Hukum Progresif (Penjelajahan Suatu Gagasan) disampaikan pada jumpa alumni Program Doktor Ilmu Hukum Universitas Diponegoro Semarang, tanggal 4 september 2004.

2009. Lapisan-Lapisan dalam Studi Hukum. Banyumedia Publishing. Malang.

2004. Menuju Produk Hukum Progresif. Makalah Diskusi Terbatas pada Fakultas Hukum UNDIP. Semarang, tanggal 24 Juni 2004.

2005. Hukum Progresif. Hukum yang Membebaskan. Jurnal Hukum Progresif, Vol. 1/No. 1/April 2005, PDIH UNDIP, Semarang.

-------, 2007. Membedah Hukum

Progresif. Buku Kompas. Jakarta.

-------, 1980. Hukum dan Mayarakat. Angkasa. Bandung.

Ranuhandoko, I.P.M. Terminologi Hukum, Cetakan Kedua, Jakarta: Sinar Grafika, 2000, 
Ronny Hanitijo Soemitro, 1990. Soerjono Soekanto. 1986. Pengantar Metodologi Penelitian Hukum Penelitian Hukum. Universitas dan Jurimetri, : Ghalia Indonesia, Jakarta.

Siahaan, Maruarar. 2008. UUD 1945 sebagai Konstitusi yang Hidup. Sekretariat Jenderal Mahkamah Konstitusi. Jakarta.

---------,2007. Aspek Teoritis dan Implementasi Putusan Mahkamah Konstitusi pada Perkara Pengujian UndangUndang, Makalah pada Rapat Koordinasi Pusat Kajian Konstitusi Se-Indonesia. Jakarta.

Sudijono SA, Konfigurasi Hukum Progresif, Jurnal Ilmu Hukum, FH Undip, Vol. 8, No. 2, September 2005. Indonesia Perrss. Jakarta Strong, C.F. 1963. Political Constitution. Sidgwick and Jackson Ltd.London.

Tanya, Bernard L., dkk. 2006. Teori Hukum. Strategi Tertib Manusia Lintas Ruang dan Generasi, CV. KITA: Surabaya.

Undang-Undang Dasar Negara Republik Indonesia Tahun 1945 Dalam Satu Naskah.

Undang-Undang Nomor 23 Tahun 2004 tentang Mahkamah Konstitusi.

Undang-Undang Nomor 48 Tahun 2009 tentang Kekuasaan Kehakiman. Undang-Undang Nomor 10 Tahun 2004 tentang Pembentukan Peraturan Perundang-Undangan. 